\title{
Helminth fauna of bovines from the Central-Western region, Minas Gerais State, Brazil
}

\author{
Fauna helmintológica de bovinos da região Centro-oeste do Estado de Minas Gerais, Brasil
}

\author{
Thaís Rabelo dos Santos ${ }^{\mathrm{I}}$ Welber Daniel Zanetti Lopes ${ }^{\mathrm{I}}$ Carolina Buzulini $^{\mathrm{I}}$ \\ Fernando de Almeida Borges ${ }^{\mathrm{I}}$ Cláudio Alessandro Massamitsu Sakamoto ${ }^{\mathrm{I}}$ \\ Roberto Cesar de Araújo Lima ${ }^{I}$ Gilson Pereira de Oliveira' ${ }^{\mathrm{I}}$ Alvimar Jose da Costa ${ }^{\mathrm{I}}$
}

\section{ABSTRACT}

Seventy-six naturally infected bovines, males and females of mixed breed, aged 8 to 12 months-old, were necropsied. The results of necropsy revealed the presence of 9 helminth genera and 16 species, with the following prevalence and mean infection intensity: Haemonchus placei $(100.0 \%$; 3895.5); Haemonchus similis (29.0\%; 159.6); Cooperia punctata (100.0\%; 5595.0); Cooperia spatulata (32.9\%; 137.8); Cooperia pectinata (34.2\%; 1010.5); Trichostrongylus axei (69.7\%; 239.2); Trichostrongylus colubriformis (10.5\%; 10.8); Trichostrongylus longyspicularis (2.6\%; 0.5); Ostertagia ostertagi $(2.6 \%$; 3.1$)$; Ostertagia lyrata (2.6\%; 1.5$)$; Ostertagia trifurcata (1.3\%; 0.3); Oesophagostomum radiatum (94.7\%; 470.9); Trichuris discolor (47.4\%; 32.5); Strongyloides papillosus (1.3\%; 0.1); Capillaria bovis (9.2\%; 1.0$)$ and Bunostomum phlebotomum $(2.6 \% ; 0.3)$. The mean parasitic load was 11,558.5 helminths per bovine. Of the 76 necropsied bovine, $92.1 \%$ were infected by 3 to 7 helminth species. Only $7.9 \%$ of hosts were parasitized by 8 different helminth species. This study includes the first report of the species Ostertagia lyrata and Ostertagia trifurcata in Minas Gerais state. It should be emphasized that while identifying the helminths collected during necropsy in the present work, observation revealed that an inversion in the mean parasitic intensity is occurring, showing diminishing numbers of Cooperia and an increase in Haemonchus compared to the values reported in the literature.

Key words: prevalence, gastrointestinal nematodes, bovine.

RESUMO

A prevalência e a intensidade de parasitismo por diferentes espécies de helmintos foram estudadas em bovinos da microrregião de Formiga, região Centro-oeste de Minas Gerais. Para tanto, foram necropsiados 76 bovinos naturalmente infectados, machos e fêmeas, SRD (sem raça definida) e de oito a 12 meses de idade. Os resultados necroscópicos revelaram a presença de nove gêneros e 16 espécies de helmintos, com a seguinte prevalência e média de intensidade de infecção: Haemonchus placei (100,0\%; 3895,5); Haemonchus similis $(29,0 \%$; 159,6); Cooperia punctata (100,0\%; 5595,0); Cooperia spatulata $(32,9 \% ; 137,8)$; Cooperia pectinata $(34,2 \% ; 1010,5)$; Trichostrongylus axei (69,7\%; 239,2); Trichostrongylus colubriformis (10,5\%; 10,8); Trichostrongylus Iongyspicularis (2,6\%; 0,5); Ostertagia ostertagi $(2,6 \% ; 3,1)$; Ostertagia lyrata $(2,6 \% ; 1,5)$; Ostertagia trifurcata $(1,3 \% ; 0,3)$; Oesophagostomum radiatum $(94,7 \%$; 470,9); Trichuris discolor (47,4\%; 32,5); Strongyloides papillosus (1,3\%; 0,1); Capillaria bovis $(9,2 \% ; 10) e$ Bunostomum phlebotomum $(2,6 \% ; 0,3)$. A carga parasitária média foi de 11.558,5 helmintos por animal. Dos 76 bovinos necropsiados, 92,1\% estavam infectados por três a sete espécies de helmintos. Apenas 7,9\% dos hospedeiros mostravam-se parasitados por oito espécies diferentes de helmintos. Este estudo mostra o primeiro relato das espécies Ostertagia lyrata e Ostertagia trifurcata no Estado de Minas Gerais. É importante ressaltar que, no presente trabalho, por meio da identificação dos helmintos colhidos nas necropsias, foi possível observar que está ocorrendo uma inversão na intensidade parasitária média, com uma diminuição no número de Cooperia e um aumento nos valores de Haemonchus, em comparação com os valores relatados na literatura.

Palavras-chave: prevalência, helmintos, bovinos.

\section{INTRODUCTION}

Infections by gastrointestinal nematodes in ruminants cause extensive economic losses resulting

'Departamento de Patologia Animal, Centro de Pesquisa em Sanidade Animal, (CPPAR), Faculdade de Ciências Agrárias e Veterinárias (FCAV), Universidade Estadual Paulista (UNESP). Via de acesso Prof. Paulo Donatto Castellane, s/n, 14884-900, Jaboticabal, SP, Brasil. E-mail: rabelo.vet@hotmail.com. Autor para correspondência. 
from mortality and morbidity, characterized by diminished productivity in these animals (LIMA \& GUIMARÃES, 1992). Gastrointestinal verminosis, identified as one of the principal factors that spoils meat production, acts in a subclinical form in extensively bred beef cattle, damaging the development of the breeding and rebreeding phases and reducing resistance to infections caused by bacteria and viruses.

The control of these parasites is principally based on treating cattle with anthelmintics; however, this practice is not always effective due to the ever more frequent appearance of resistant helminth populations (SOUTELLO et al., 2003). A system of sanitary and zootechnical management, associated with epidemiological studies, could minimize the use of endectocides.

Antiparasitic control should be based on knowledge of the helminth species present in bovine from the region, as well as their epidemiology. With this objective, numerous studies to establish infection indicators in Brazil have been realized in the southwestern region by LANDIM et al. (2001); centralwestern region by CATTO \& UENO (1981); southern region by SANTOS et al. (1994); and the northeastern region by LEAL et al. (1999).

In Minas Gerais State, existing studies concerning the helminth fauna, epidemiology, pathogenesis and helminth control in bovine herds are scarce and fragmented, with an absence of data concerning such knowledge in the majority of the microregions (MELO \& RIBEIRO, 1977). The objective of this study was to determine the occurrence of gastrointestinal nematode in bovine of the Formiga micro-region in the central-western region of Minas Gerais State, Brazil.

\section{MATERIALS AND METHODS}

The research was realized from January 2006 to December 2007, involving 76 bovine originating from a herd situated in the Formiga micro-region, $\left(20^{\circ} 27^{\prime} \mathrm{S}\right.$, $45^{\circ} 25^{\prime} \mathrm{W}$ ), which extends over $4,564,361 \mathrm{~km}^{2}$ in the central-western of the Minas Gerais State, in Southeast Brazil (IBGE, 2006). The region is mainly hilly and is 785 - $1125 \mathrm{~m}$ above sea level. The average annual temperature is $21.8^{\circ} \mathrm{C}$ and the average annual rainfall index is $1272 \mathrm{~mm}$. According to the Köppen classification, the climate is of type Cwa (i.e., mesothermic with hot and rainy summers and dry winters).

Males and female bovines of mixed breed (dutch $\mathrm{x}$ zebu), aged 8 to 12 months-old, demonstrated a reasonable state of nutrition and were naturally infected by gastrointestinal helminths. The cattle were selected by means of EPG counts, using the technique of GORDON \& WHITLOCK (1939), selecting only those with EPG counts over 500.

After selection, the bovines were transported and maintained in suspended individual bays in the bovine section of CPPAR (Animal Sanitation Research Center/ Centro de Pesquisas em Sanidade Animal) FCAV/UNESP, where they received commercial feed and corn silage (twice daily) and water ad libitum. Later, the bovine were necropsied using anesthetics according to regulatory norms recommended for scientific research.

During the necropsies, collection of the material was realized according to the parasitological methodology of JACOBS et al. (1994). All the contents and scrapings from each anatomical segment (abomasum, duodenum, jejunum, ileum, cecum, colon and rectum) were placed on a sieve (Tyler 48, opening $0.297 \mathrm{~mm}$ ) and washed. Each individual abomasum was submitted to digestion with a pepsin hydrochloric solution. The remaining organs were also examined and any intact helminths were collected (WOOD et al., 1995; VERCRUYSSE et al., 2001). The solid part was fixed in $5 \%$ formol and heated to $80^{\circ} \mathrm{C}$. The collection, counting and generic identification of the parasites of each organ were carried out according to LEVINE (1968) and UENO \& GONÇALVES (1998).

The infection indicators were calculated according to MARGOLIS et al. (1982). The values for helminth prevalence were calculated based on the number of infected bovine for each helminth collected.

\section{RESULTS AND DISCUSSION}

The results of necropsy revealed the presence of nine helminth genera and 16 species, with the prevalence and mean infection intensity (Table 1).

The mean parasitic load was $11,558.5$ helminths per bovine. Identification of the helminths collected at necropsy revealed that Haemonchus and Cooperia corresponded to $35.1 \%$ and $58.3 \%$ of the mean parasitic load, respectively, and that Haemonchus placei and Cooperia punctata were the most frequently observed species. The percentage distribution of cases of registered infection according to the number of helminth species present in the same host is shown in table 2. Analysis of table 2 showed that $92.1 \%$ of the bovine were infected by three to seven helminth species. Only 7.9\% of hosts were parasitized by eight different helminth species in their digestive tract. 
Table 1 - Prevalence, mean intensity and total amplitude of the variation in infection by helminths in bovine of the Formiga micro-region, MG, Brazil.

\begin{tabular}{|c|c|c|c|c|c|c|}
\hline \multirow{4}{*}{$\begin{array}{l}\text { Helminth species } \\
\text { Haemonchus placei } \\
\text { Haemonchus similis }\end{array}$} & \multirow{4}{*}{$\begin{array}{l}\text { Prevalence } \\
100.00 \\
28.95\end{array}$} & \multirow{3}{*}{$\frac{\text { Mean (species) }}{3895.50}$} & \multirow{4}{*}{$\begin{array}{c}\text { Mean (genera) } \\
4055.08\end{array}$} & \multirow{4}{*}{$\begin{array}{c}\text { Percentage (genera) } \\
35.0832\end{array}$} & \multirow{2}{*}{\multicolumn{2}{|c|}{ Amplitude of variation }} \\
\hline & & & & & & \\
\hline & & & & & 85 & 24327 \\
\hline & & 159.58 & & & 0 & 5251 \\
\hline Trichostrongylus axei & 69.74 & 239.22 & & & 0 & 3191 \\
\hline Trichostrongylus colubriformis & 10.53 & 10.79 & 250.54 & 2.1676 & 0 & 640 \\
\hline Trichostrongylus longyspicularis & 2.63 & 0.53 & & & 0 & 23 \\
\hline Cooperia punctata & 100.00 & 5594.95 & & & 10 & 35534 \\
\hline Cooperia spatulata & 32.89 & 137.83 & 6743.32 & 58.3410 & 0 & 1954 \\
\hline Cooperia pectinata & 34.21 & 1010.54 & & & 0 & 69758 \\
\hline Ostertagia ostertagi & 2.63 & 3.12 & & & 0 & 131 \\
\hline Ostertagia lyrata & 2.63 & 1.47 & 4.86 & 0.0420 & 0 & 90 \\
\hline Ostertagia trifurcata & 1.32 & 0.26 & & & 0 & 20 \\
\hline Oesophagostomum radiatum & 94.74 & 470.89 & 470.89 & 4.0740 & 0 & 2890 \\
\hline Trichuris discolor & 47.37 & 32.51 & 32.51 & 0.2813 & 0 & 940 \\
\hline Strongyloides papillosus & 1.32 & 0.07 & 0.07 & 0.0006 & 0 & 5 \\
\hline Capillaria bovis & 9.21 & 0.93 & 0.93 & 0.0081 & 0 & 20 \\
\hline Bunostomum phlebotomum & 2.63 & 0.26 & 0.26 & 0.0023 & 0 & 10 \\
\hline TOTAL & - & 11558.46 & 11558.46 & 100.00 & 500 & 87025 \\
\hline
\end{tabular}

Similar to that observed by OLIVEIRA (1988) and OLIVEIRA \& MATSUMOTO (1985), the species with the greatest prevalences were Haemonchus placei (100.0\%) and Cooperia punctata (100.0\%), followed by Oesophagostomum radiatum (94.7\%). However, this result is in disagreement with that reported by other authors in the State of São Paulo (LANDIM et al., 2001) and the remaining regions of the country (BIANCHIN et al., 1996; LEAL et al., 1999). It should be noted that the greater infection intensity presented by Cooperia spp (58.3\%) in relation to Haemonchus spp (35.1\%), is similar to results previously reported by the authors

Table 2 - Percentage distribution of the cases of registered infection, according to the number of helminth species present in the same host of the Formiga micro-region, MG, Brazil.

\begin{tabular}{|c|c|c|}
\hline \multirow{2}{*}{ Number of species } & \multicolumn{2}{|c|}{---------Infected bovine--------- } \\
\hline & Quantity & Percentage \\
\hline 1 & 0 & 0.0 \\
\hline 2 & 0 & 0.0 \\
\hline 3 & 9 & 11.8 \\
\hline 4 & 11 & 14.5 \\
\hline 5 & 20 & 26.3 \\
\hline 6 & 18 & 23.7 \\
\hline 7 & 12 & 15.8 \\
\hline 8 & 6 & 7.9 \\
\hline Total & 76 & 100.0 \\
\hline
\end{tabular}

cited above. However, in the present work, analysis of the results determined that a reduction occurred in the total number of Cooperia, while the number of Haemonchus increased.

The prevalence of $\boldsymbol{O}$. radiatum was high (94.7\%), with a mean infection intensity of 470.9 , though this was lower than both Cooperia spp and Haemonchus spp. LANDIM et al. (2001) indicated this large intestine nematode as the second most prevalent in the northeastern region of the State of São Paulo, as did MELO \& RIBEIRO (1977) in the State of Mato Grosso do Sul.

For the genus Trichostrongylus spp, a mean of 250.5 parasites were recovered, representing only $2.2 \%$ of the total parasitic load, with the following species: T. axei, T. colubriformis and T. longyspiculares, showing a prevalence of $69.7 \%, 10.5 \%$ and 2.6\%, respectively. This result is in agreement with those obtained by DUARTE et al. (1982) and OLIVEIRA \& MATSUMOTO (1985). According to ROBERTS et al. (1952) and LEE et al. (1960), high temperatures negatively influence the preinfective states of these species; a fact confirmed by SANTOS et al. (1994), who determined that Trichostrongylus spp. was the most prevalent genus in São Francisco de Paula, Rio Grande do Sul State, in the coolest region of the country. For this reason, $\boldsymbol{O}$. ostertagi, $\boldsymbol{O}$. lyrata and $\boldsymbol{O}$. trifurcate presented low prevalences $(2.6 \%, 2.6 \%$ and $1.3 \%$, respectively) and mean infection intensities (3.1, 1.5 and 0.3 , respectively). 
This study is the first report of the species O. lyrata and $\boldsymbol{O}$. trifurcate parasitizing in Minas Gerais State.

The species Trichuris discolor presented a prevalence of $47.4 \%$ a result greater than that obtained by OLIVEIRA \& MATSUMOTO (1985) in the region of São Carlos, SP; by DUARTE et al. (1982) in Cantagalo, RJ; and by CARNEIRO \& FREITAS (1977) in Goiás, though lower than the prevalence (79.3\%) obtained in Minas Gerais by COSTA et al. (1970).

The low prevalences of $\boldsymbol{S}$. papillosus (1.3\%) and B. phlebotomum (2.6\%) could be associated with the age range of the necropsied bovines, 8 to twelve months-old, since from five months of age onwards, bovines begin to present resistance to these species (ROBERTS et al., 1952; VEGORS, 1954; COSTA et al., 1979).

\section{CONCLUSIONS}

Based on the results obtained in the present work, it can be concluded that the two most abundant helminth genera in the Formiga micro-region in Minas Gerais State and in the 76 parasitological necropsies were Cooperia (58.3\%) and Haemonchus (35.1\%). Moreover, it is important to highlight that an inversion in the mean parasitic intensity was observed in the present study, showing diminishing numbers of Cooperia and an increase in Haemonchus in comparison with reports in the literature (BIACHIN et al., 1996). Ostertagia lyrata and Ostertagia trifurcata are described parasitizing bovine in the Minas Gerais state for the first time.

\section{REFERENCES}

BIANCHIN, I. et al. Epidemiologia dos nematódeos gastrintestinais em bovinos de corte nos cerrados e o controle estratégico no Brasil. Cidade sede Campo Grande: Embrapa-CNPGC, 1996. 120p. (Circular Técnica 24).

CARNEIRO, J.R.; FREITAS, M.G. Curso natural de infecções helmínticas gastrintestinais em bezerros nascidos durante a estação chuvosa em Goiás. Arquivos da Escola de Veterinária da Universidade Federal de Minas Gerais (Brasil), v.29, p.49-51, 1977

CATTO, J.B.; UENO, H. Nematodioses gastrintestinais em bezerros zebu do Pantanal matogrossense. I - Prevalência, intensidade de infecção e variação estacional. Pesquisa Agropecuária Brasileira, v.16, p.129-140, 1981.

COSTA, A.J. et al. Helmintos parasitos de bezerros do município de Uruana Goiás, Brasil. Arquivos da Escola de Veterinária da Universidade Federal de Minas Gerais, v.31, p.33-36, 1979.
COSTA, H.M.A. et al. Prevalência e intensidade de infestação por helmintos de bovinos procedentes da área de Três Corações. Arquivos da Escola de Veterinária da Universidade Federal de Minas Gerais (Brasil), v.22, p.95-101, 1970.

DUARTE, M.J.F. et al. Prevalência e intensidade de infecção helmíntica em bezerros de Cantagalo, RJ, Brasil. Pesquisa Agropecuária Brasileira, v.17, p.1521-1524, 1982.

GORDON, H.M.; WHITLOCK, H.V. A new technique for counting nematode eggs in sheep faeces. Journal of the Council for Scientific and Industrial Research, v.12, p.5052, 1939.

IBGE, Produção da Pecuária Municipal, 2006. Malha municipal digital do Brasil: situação em 2006. Rio de Janeiro: IBGE, 2007. 62p.

JACOBS, D.E. et al. World Association for the Advancement of Veterinary Parasitology (W.A.A.V.P.): guidelines for evaluating the efficacy of anthelmintics for dogs and cats. Veterinary Parasitolology, v.52, p.179-202, 1994.

LANDIM, V.J.C. et al. Parasitic nematodes in weaned calves from the north-east region of São Paulo State, Brazil. ARS Veterinária, v.17, p.42-50, 2001.

LEAL, J.A. et al. Verminose bovina. Teresina: Embrapa Meio-Norte; 1999. 41p.

LEE, R.P. et al. The seasonal variations of Strongyle infestations in Nigerian Zebu cattle. British Veterinary Journal, v.116, p.34-46, 1960.

LEVINE, N.D. Nematode parasites of domestic animals and of man. Minneapolis: Burgess, 1968. 600p.

LIMA W.S.; GUIMARÃES, M.P. Comportamento das infecções helmínticas em vacas de rebanho de corte durante a gestação e lactação. Arquivo Brasileiro de Medicina Veterinária e Zootecnia, v.44, p.387-396, 1992.

MARGOLIS, L. et al. The use of ecological terms in parasitology (report of an ad hoc committee of the American Society of Parasitologists). Journal of Parasitology, v.68, p.131-133, 1982.

MELO, H.J.H.; RIBEIRO, H.S. Helmintos parasitas dos animais domésticos no Estado do Mato Grosso. Arquivos da Escola de Veterinária da Universidade Federal de Minas Gerais, v.29, p.161-164, 1977.

OLIVEIRA, G.P. Epidemiologia dos nematódeos gastrintestinais de bovinos leiteiros no município de São Carlos, Estado de São Paulo. Pesquisa Agropecuária Brasileira, v.23, p.189195, 1988.

OLIVEIRA, G.P.; MATSUMOTO, T. Prevalência e intensidade de infecção por helmintos em bovinos da bacia leiteira de São Carlos, São Paulo. Pesquisa Agropecuária Brasileira, v.20, p.1415-1418, 1985

ROBERTS, F.H.S. et al. The epidemiology of parasitic gastroenteritis of cattle. Australian Journal of Agricultural Research, v.3, p.187-226, 1952. 
SANTOS, I.C.S. et al. Verminose bovina no distrito de Lajeado Grande, São Francisco de Paula - RS. Lavoura arrozeira, v.47, p.6-14, 1994.

SOUTELLO, R.V.G. et al. The prevalence of anthelmintic resistance in nematode parasites of cattle in Sao Paulo state, Brazil. In: INTERNATIONAL CONFERENCE OF THE WORLD ASSOCIATION FOR THE ADVANCEMENT OF VETERINARY PARASITOLOGY, 19, 2003, New Orleans, USA. Proceedings... New Orleans: Louisiana State University and WAAVP 2003 Local Organizing Committee, 2003. 275p.

UENO, H.; GONÇALVES, P.C. Manual para diagnóstico das helmintoses de ruminantes. 4.ed. Tóquio: Japan International Cooperation Agency, 1998. 143p.

VEGORS, H.H. Experimental infection of calves with Strongyloides papillosus (Nematoda). American Journal of Veterinary Research, v.15, p.429-433, 1954.

VERCRUYSSE, J. et al. International harmonization of anthelmintic efficacy guidelines. Veterinary Parasitology, v.96, p.171-193, 2001. Available from: <http:// w w w. s c i e n c e d i r e c t . c o m / science?_ob=MImg\&_imagekey=B6TD7-42G0KJG$17 \&$ \&di $=5191 \&$ \&user $=972052 \&$ \&orig=browse\&_cover Date=04\%2F02\%2F2001\&_sk=999039996\&view=c\&wchp=dGLbVzbzSkWz\&md5=12c67c3725528462c3c11744559022ce\&ie $=$ / sdarticle.pdf $>$. Accessed: nov 26, 2009. doi:10.1016/S03044017(00)00443-X.

WOOD, I.B. et al. World Association for the Advancement of Veterinary Parasitology (W.A.A.V.P.), second edition of guidelines for evaluating the efficacy of anthelmintics in ruminants (bovine, ovine, caprine). Veterinary Parasitology, v.58, p.181-213, 1995. Available from: <http://www.sciencedirect.com/ science?_ob=ArticleURL\&_udi=B6TD7-3YYTGV5C \& _ u s e r $=972052 \&$ \& c o v e r D a t e $=06 \%$ 2F30\%2F1995\&_rdoc=1\&_fmt=high\&_orig=browse\&_srch=docinfo ( \% 23 t o c \% $235191 \% 231995 \% 23999419996$ \% $23182154 \% 23$ F L P \% 23 dis p l a y \% $23 \mathrm{Volu}$ me)\&_cdi $=51918$ \&sort $=$ d\&_docanchor $=$ \&_ct $=7 \&$ \&acct $=$ C00004 96478 \&_version $=1$ \&_urlversion $=0$ \&_userid $=$ $972052 \& m d 5=c 3078$ c4f9ff75bdff24b2ff8e6945e13>. Accessed: nov 26, 2009. doi:10.1016/0304-4017(95)00806-2. 